\title{
THE ENDURING VULNERABILITY OF MIGRANT DOMESTIC WORKERS IN EUROPE
}

\author{
Clíodhna Murphy*
}

\begin{abstract}
While the rights of domestic workers are expanding in international law, including through the adoption of the ILO Domestic Workers Convention in 2011, migrant domestic workers remain particularly vulnerable to employment-related abuse and exploitation. This article explores the intersection of the employment law and migration law regimes applicable to migrant domestic workers in the United Kingdom, France and Ireland. The article suggests that the precarious immigration status of many migrant domestic workers renders employment protections, such as they exist in each jurisdiction, largely illusory in practice for this group of workers. The labour standards contained in the Domestic Workers Convention, together with the recommendations of the UN Committee on Migrant Workers on the features of an appropriate immigration regime for migrant domestic workers, are identified as providing an alternative normative model for national regulatory frameworks.
\end{abstract}

Keywords: Article 4 ECHR, employment law, ILO Convention, immigration law, migrant domestic workers.

\section{INTRODUCTION: MIGRANT DOMESTIC WORKERS IN EUROPE}

Recent decades have witnessed the resurgence of paid domestic work in Europe, in parallel with the increase in female participation in the labour force. ${ }^{1}$ Many of the 'new' domestic workers are migrant women, often employed by middle-class women who may prefer to outsource the 'three C's' (cooking, cleaning and caring) ${ }^{2}$ to women 'different from themselves'. 3 Migrant domestic workers are recognized as being particularly susceptible

* Lecturer in Law, Dublin City University, cliodhna.murphy@dcu.ie. The author would like to acknowledge the support received from an Irish Research Council Senior Fellowship Award. The author would also like to thank Professor Siobhán Mullally for her valuable comments on earlier drafts of this article.

${ }^{1}$ G Ozyegin and P Hondagneu-Sotelo, 'Domestic Work, Migration and the New Gender Order in Contemporary Europe', in H Lutz (ed) Migration and Domestic Work: A European Perspective on a Global Theme (Ashgate 2008) 195.

2 B Anderson, Doing the Dirty Work? The Global Politics of Domestic Labour (Zed Books 2000).

Ozyegin and Hondagneu-Sotelo (n 1) 199; B Anderson, 'A Very Private Business: Exploring the Demand for Migrant Domestic Workers' (2007) 14(3) European Journal of Women's Studies 247. 
to abuse and exploitation, with this vulnerability attributable to a number of factors including the isolated and invisible nature of their work, ${ }^{4}$ their level of dependence on their employer (for income, accommodation and immigration status), ${ }^{5}$ a lack of clear legal regulation of the specific occupational challenges which they face, ${ }^{6}$ and often a restrictive immigration status. ${ }^{7}$ A common thread running through these concerns is the power imbalance between employer and employee in the domestic-work scenario, which may be exacerbated by restrictions on employment and access to social security associated with the immigration status of the worker. ${ }^{8}$ As Anderson observes, immigration law moulds migrant domestic workers (like other low-waged migrant workers) into 'precarious workers', their situation characterized by instability, lack of protection, insecurity and social or economic vulnerability. ${ }^{9}$ All of these factors are further compounded by multiple, intersecting forms of discrimination based on class, race, nationality and gender, with migrant domestic workers caught 'at the intersection of care work exploitation with gender, ethnic and migrant oppression in the context of a globalising world'. ${ }^{10}$

Migrant domestic workers frequently suffer from a 'decent work deficit' ${ }^{11}$ as well as restricted access to family reunification and limited access to education, health care and housing. ${ }^{12}$ Specific manifestations of the decent work deficit include low wages and non-payment of wages, excessive and undefined work hours, insufficient rest and leisure time, a lack of social security protection and exposure to psychological and physical abuse. ${ }^{13}$ These problems are largely

${ }^{4}$ See, for example, MA Chen 'Recognizing Domestic Workers, Regulating Domestic Work: Conceptual, Measurement, and Regulatory Challenges' (2011) 23 Canadian Journal of Women and the Law 167; UN Office of the High Commissioner for Human Rights, 'Rights of Migrant Domestic Workers in Europe' (2010) 7.

${ }_{6}^{5}$ UN Office of the High Commissioner for Human Rights (n 4$) 4$.

${ }^{6}$ UN Office of the High Commissioner for Human Rights (n 4) 6; Chen (n 4) 169-70.

7 A Blackett, 'Introduction: Regulating Decent Work for Domestic Workers' (2011) 23 Canadian Journal of Women and the Law 1.

${ }^{8}$ See, for example, B Anderson, 'Migration, Immigration Controls and the Fashioning of Precarious Workers' (2010) 24(2) Work, Employment \& Society 300.

9 ibid 303.

${ }^{10}$ F Williams, 'Migration and Care: Themes, Concepts and Challenges' (2010) 9(3) Social Policy and Society 385 .

${ }_{11}$ M Tomei, 'Decent Work for Domestic Workers: Reflections on Recent Approaches to Tackle Informality' (2011) 23 Canadian Journal of Women and the Law 186, 187. See also A D'Souza, 'Moving towards Decent Work for Domestic Workers: An Overview of the ILO's Work' (2010) ILO Working Paper 2/2010, 19.

${ }_{12}$ See EU Fundamental Rights Agency (FRA) Report, 'Migrants in an Irregular Situation Employed in Domestic Work: Fundamental Rights Challenges for the European Union and its Member States' (2011). For regular migrants, this is the case where recourse to 'public funds' is prohibited by the terms of their visa. In the UK context, see generally J Pobjoy and S Spencer, 'Equality for All? The Relationship between Immigration Status and the Allocation of Rights in the United Kingdom' (2012) 2 European Human Rights Law Review 160.

${ }_{13}$ Committee on the Protection of the Rights of all Migrant Workers and Members of Their Families, General Comment No 1 on Migrant Domestic Workers (UN Doc CMW/C/GC/1, 23 February 2011) (CMW General Comment) para 13. 
unseen for the rest of society, with the classic gendered divide between the public and the private spheres partly explaining the lack of public attention given to exploitation of domestic workers. ${ }^{14}$

Developments in international law have begun to recognize the specific rights-protection gaps experienced by domestic workers, and in particular migrant domestic workers. The adoption of the International Labour Organization's (ILO) Domestic Workers Convention (Domestic Workers Convention) and Supplementary Recommendation, ${ }^{15}$ along with a General Comment of the UN Committee on Migrant Workers and their Families ${ }^{16}$ on migrant domestic workers and a General Recommendation of the UN Committee for the Elimination of All Forms of Discrimination against Women (CEDAW Committee) on women migrant workers ${ }^{17}$ constitute an acknowledgement of the need for specific human rights protections for domestic workers. At a regional level, the European Court of Human Rights has established and developed the positive obligations of states to protect individuals from slavery, servitude and forced labour (as prohibited under Article 4 of the European Convention on Human Rights) in Siliadin $v$ France, ${ }^{18}$ C.N. and $V v$ France $^{19}$ and C.N. $v$ United Kingdom ${ }^{20}$-all cases taken by migrant domestic workers.

Against this background, this article considers two dimensions of the role of the State in 'creating and perpetuating' the principal structural disadvantages faced by migrant domestic workers: working in a precarious employment sector and being subject to restrictive migration controls. ${ }^{21}$ It addresses the intersection of employment law and migration regimes through a three-country study of France, the UK and Ireland. As will be seen in the course of the article, the detailed legal framework for the regulation of the domestic work sector in France, the recent launch of an innovative inspection scheme of private homes aimed at improving enforcement of employment protections in Ireland, and recent legislative changes to the immigration regime for domestic workers in the UK are among the reasons why these jurisdictions have been selected.

The analysis shows that while the approaches of the three jurisdictions in respect of the labour regulatory framework for domestic work differ

${ }^{14}$ H Lutz, 'Gender in the Migratory Process' (2010) 36(10) Journal of Ethnic and Migration Studies $1647,1652$.

${ }^{15}$ Convention Concerning Decent Work for Domestic Workers, International Labour Organisation, adopted at the 100th session of the International Labour Conference, Geneva, 2011.

${ }^{16}$ CMW General Comment (n 13).

${ }^{17}$ Committee for the Elimination of All Forms of Discrimination Against Women, General Recommendation No 26 on Women Migrant Workers (UN Doc CEDAW/C/2009/WP.1/R, 5 December 2008) (CEDAW General Recommendation).

18 (2006) 43 EHRR 16.

19 Application No 67724/09, Judgment of 11 October 2012.

20 Application No 4239/08, Judgment of 13 November 2012.

${ }^{21}$ Blackett (n 7) 4. 
considerably, the trend in each of the national immigration regimes is towards restricting access to the labour market and a secure legal status for migrant domestic workers. This convergence reflects a Europe-wide trend for encouraging 'highly skilled workers' over other types of worker, together with the perception of domestic work as unskilled and lacking in economic value. It is argued that the short-term, precarious immigration status of many migrant domestic workers renders employment protections, such as they exist in each jurisdiction, largely illusory in practice for this group of workers. It will be seen that in France and Ireland (although not in the UK), governments have started to acknowledge the impact of their employment laws on domestic workers and there are elements of good practice contained in the employment frameworks applicable in those jurisdictions. There is, however, no corresponding acknowledgement in any of the three jurisdictions under consideration, of the nexus between immigration policies and the vulnerability of migrant domestic workers. Illustrating this point, the relatively progressive immigration regime enshrined in UK law for migrant domestic workers between 1998 and 2012 (which allowed workers to change employer, apply to have dependants join them in the UK and eventually apply for long-term residence) has been rolled back and replaced by a temporary and insecure visa which ties workers to their employer.

The lack of effective protection afforded by employment law, which is compounded by the precariousness created by immigration law, leads to serious gaps in the protection of the human rights of migrant domestic workers. The article thus underlines the importance of recognizing the interaction of employment and migration regimes in assessing effective access to employment-related rights for migrant domestic workers. In this regard, it assesses the principles and measures contained in the Domestic Workers Convention and the UN Committee on Migrant Workers' General Comment in order to identify where best practice lies for these regulatory regimes. It argues that these standards provide much-needed specific guidance for states in constructing appropriately protective regulatory regimes.

The final part of the article evaluates the role of the jurisprudence of the European Court of Human Rights under Article 4 of the European Convention of Human Rights (ECHR) in terms of addressing protection gaps in national regulatory frameworks. While the impact of the Court's work to date, in requiring states to criminalize and deter forced labour is acknowledged, it is suggested that the legal framework of Article 4 is, of itself, inadequate to deal with labour law violations experienced by migrant domestic workers which do not reach the threshold of severity of slavery, servitude or forced labour. In this context, positive engagement of governments with the international standard setting initiatives undertaken by the ILO and the UN Committee on Migrant Workers provides the best way forward in terms of ensuring improved rights protection for migrant domestic workers. 
II. APPROACHES TO REGULATING DOMESTIC WORK: DIVERGENCE, COMMONALITY AND THE VALUE OF INTERNATIONAL STANDARDS

\section{A. Regulatory Challenges and the Normative Model Provided by the Domestic Workers Convention}

The low monetary value placed on domestic work is associated with its location in the private sphere of the home and its status as 'reproductive' labour, as defined by Salazar Parrenas as 'labour activities needed to sustain the productive labour force' through tasks including household chores and the care of the elderly and children. ${ }^{22}$ This 'reproductive labour' is usually associated with tasks performed by female household members without pay and consequently perceived as unskilled and lacking in value. ${ }^{23}$ For the same reasons, domestic work is often thought to fall outside the 'normal' employment regulation framework and is sometimes excluded completely from it. The isolated nature of domestic work adds to such workers' vulnerability and, even when regulated, enforcement of employment protections can prove difficult due to the location of the work within private households. ${ }^{24}$ As already mentioned, the economy of domestic care is increasingly 'transnational' in nature, with low-paid domestic help often provided by migrant workers who are classified as 'low-skilled' workers. ${ }^{25}$ It will be seen below that the precarious immigration statuses which are common for 'low-skilled' migrants make it difficult for migrant domestic workers to pursue legal remedies against employers, rendering them particularly vulnerable to exploitation and abuse.

Despite these difficulties, the fundamental assumption underlying the Domestic Workers Convention is the transformative potential of a labour law framework which recognizes the specificity of domestic work and constructs such work, within a decent work paradigm, as a 'proper' job. ${ }^{26}$ The Domestic Workers Convention is the first international instrument to address the specificity of domestic work and the protection needs of domestic workers. As stated in the report which preceded its negotiation, the Convention is

22 RS Parrenas, 'Migrant Filipina Domestic Workers and the International Division of Reproductive Labor' (2000) 14(4) Gender and Society 560.

${ }^{23}$ International Labour Conference, 99th Session, 2010, Decent Work for Domestic Workers (Report IV(1)) (ILO Report on Decent Work for Domestic Workers (Report IV(1))) 5.

${ }^{24}$ P Smith, 'The Pitfalls of Home: Protecting the Health and Safety of Paid Domestic Workers (2010) Canadian Journal of Women and the Law 309, 311. See also P Smith, 'Aging and Caring in the Home: Regulating Paid Domesticity in the Twenty-First Century' (2007) 92 Iowa Law Review 1835 .

${ }^{25}$ See generally F Williams, 'Converging Variations in Migrant Care Work in Europe' in D Brennan and F Williams (eds) 'Care Markets and Migration in a Globalising World' (2012) 20(4) Journal of European Social Policy. See also L Benería, 'The Crisis of Care, International Migration and Public Policy' (2008) 14(3) Feminist Economics 1.

${ }^{26}$ ILO Report on Decent Work for Domestic Workers (Report IV(1)) (n 23) 13. 
intended to provide 'specific, constructive guidance on how to effectively regulate a category of worker that is singularly in need of support' ${ }^{27}$

The standards contained in the Convention are wide-ranging and address every aspect of the domestic employment relationship. States are required to ensure that domestic workers can enjoy fair terms of employment and decent working conditions. ${ }^{28}$ To address the information deficit often faced by domestic workers working in isolated situations, workers must be informed of their terms and conditions of employment in an easily understandable manner. ${ }^{29}$ Domestic workers should enjoy equality with other workers regarding working time. ${ }^{30}$ Express entitlements to the minimum wage, ${ }^{31}$ healthy and safe working conditions, ${ }^{32}$ and equal treatment with other workers in respect of social security protection (including maternity) ${ }^{33}$ are included in the Convention. ${ }^{34}$ The Convention also requires states to introduce measures providing for effective and accessible dispute resolution mechanisms for domestic workers. ${ }^{35}$ Pursuant to Article 5, states must provide 'effective protection' against abuse, harassment and violence.

The specific category of migrant domestic workers is addressed in Article 8 of the Convention, which requires that migrant domestic workers receive a written job offer or a contract of employment prior to crossing the national borders. Article 8(3) also provides that ILO Members shall take measures to cooperate with each other to ensure the effective application of the provisions of the Convention to migrant domestic workers. The need to effectively protect migrant domestic workers against abusive practices is referred to in Article 15, which deals with the regulation of private employment agencies. Notwithstanding these important references, the Convention inevitably deals with migrant domestic workers as 'workers' rather than as migrants. This means that the key issues of the lack of opportunities for legal migration as a domestic worker in many states and the appropriate immigration status to be granted to such workers are not dealt with.

Notwithstanding the limited nature of the specific references to migrants, the Convention provides a basic set of standards for a model regulatory framework to deal with the employment-related issues faced by migrant domestic workers. As the ILO has stated, it 'can play an important role in the design of labour law for domestic workers' ${ }^{36}$ It provides authoritative guidance on law and policy regarding domestic workers and, where ratified, it entails international law obligations for the countries concerned. ${ }^{37}$ Other international bodies have

27 ibid 2.

28 Art 6.

29 Art 7

30 Art 10 .

32 Art 13.

31 Art 11 .

In respect of health and safety regulations and social security, the Convention acknowledges the concerns of States in these areas by allowing them to apply these measures progressively, and in consultation with the relevant stakeholders.

Art 16. (2012) 4 .

36 ILO, 'Effective Protection for Domestic Workers: A Guide to Designing Labour Laws'
37 ibid. 
confirmed and reinforced the efforts of the ILO in the area of domestic work. The UN Committee for Migrant Workers, for example, confirms that the rights of migrant domestic workers 'should be dealt with within the larger framework of decent work for domestic workers' ${ }^{38}$ Both this Committee and the CEDAW Committee have, in their respective General Comment and General Recommendation, exhorted states to properly regulate domestic work by national legislation to ensure that domestic workers enjoy the same level of protection as other workers. ${ }^{39}$

The next section asks how states are dealing with the tensions and 'regulatory challenges' 40 involved in developing standards for the protection of domestic workers by considering how domestic work is reflected in the employment law frameworks of the UK, France and Ireland. None of these states have yet ratified the Domestic Workers Convention and each displayed varying attitudes during the process of its negotiation and adoption. Despite taking part in the negotiation of the Convention, ${ }^{41}$ the UK was one of only eight ILO member states to abstain from the final vote, stating that it would not be able to ratify the Convention as it did not fit with the existing UK framework which differentiates between domestic workers and other workers in a number of areas. ${ }^{42}$ While Ireland voted to adopt the Convention, it was disengaged from the negotiation and drafting process. ${ }^{43}$ Ratification is apparently under consideration by the Irish Department of Foreign Affairs. ${ }^{44}$ In contrast, France was actively involved in responding to the questionnaire and in the debates on the Convention. ${ }^{45}$ French government representatives demonstrated a willingness to acknowledge the importance of ensuring decent working and living conditions for domestic workers. ${ }^{46}$ Nonetheless, the Convention has not yet

38 CMW General Comment (n 13) para 37.

39 ibid para 37-4; CEDAW General Recommendation (n 17) para 26(b).

40 Chen (n 4).

41 See 'Report of the Committee on Domestic Workers', International Labour Conference, Provisional Record, 100th session, Geneva, June 2011.

${ }^{42}$ HL Deb Col WA242 (Baroness Wilcox) (12 October 2011). See also HC Deb cols 288-9 (Ed Davey MP) (29 June 2011).

43 Prior to drafting the convention, the ILO circulated a questionnaire to members to which the Irish State did not respond. Similarly, during the drafting negotiations the Irish government did not make a significant contribution. In the Committee on Domestic Workers the only (recorded) interventions of the Irish government related to the requirement to provide MDWs with a contract of employment prior to entering the state of employment and how that would fit with EU/EEA rights relating to free movement of workers. ILO Provisional Record, 100th Session 15 June 2011, Report of the Committee on Domestic Workers.

44 See Written Answers, 6 March 2011, Dáil Eireann Debate Vol. 758, No 1, Richard Bruton TD (in response to question from Mary Lou McDonald TD). See also Written Answers, Tuesday 22 May 2012, Dáil Eireann Debate Vol. 766, No 1, Richard Bruton TD (in response to question from Gerard Nash TD).

45 See International Labour Conference, 99th session 2010, Report on Decent Work for Domestic Workers (Report IV(2)) and ILO Provisional Record, 100th Session 15 June 2011, Report of the Committee on Domestic Workers respectively.

46 ILO Report IV(2) (n 45) para 92. 
been ratified by France and it remains to be seen whether this will take place. In January 2013, Italy became the first European country to ratify the Convention, which now has four state parties. ${ }^{47}$ States have shown a similar reluctance to be bound by the UN Convention on the Protection of the Rights of All Migrant Workers and Members of Their Families, ${ }^{48}$ and no European state is a signatory to this Convention.

\section{B. National Approaches to Regulating Domestic Work: A Job Like Any Other, Like No Other?}

\section{1. 'Specific regulation' and job creation in France}

The three jurisdictions under consideration address the issue of the regulation of domestic work in very different ways. ${ }^{49}$ The French model deals with domestic work in a highly legalized and formalized manner, within the framework of the complex hierarchy of sources which comprises employment law. The Code du Travail (Labour Code) sets out the general rules governing employment conditions. Domestic workers are covered by these general rules and are also specifically referred to in the Code. ${ }^{50}$ The Labour Code operates in conjunction with national collective agreements, which set out in detail the particulars of the relationship between the employer and the employee. ${ }^{51}$ The collective agreement relating to the employees of a private employer, ${ }^{52}$ which

47 ILO, 'Italy Ratifies the Domestic Workers Convention' (22 January 2013). In accordance with art 21, the Domestic Workers Convention will enter into force on 5 September 2013, 12 months after the date on which it was ratified by two ILO member States.

${ }^{48}$ International Convention on the Protection of the Rights of All Migrant Workers and Members of Their Families, GA res 45/158, annex, 45 U.N. GAOR Supp. (No 49A) 262, UN Doc A/45/49 (1990) entered into force on 1 July 2003.

49 This reflects the general diversity of the regulation of domestic work. See JM RamirezMachado, 'Domestic Work, Conditions of Work and Employment: A Legal Perspective' (Conditions of Work and Employment Series No 7, ILO 2003) (ILO Conditions of Work Report) 7.

${ }^{50}$ Issues relating to the regulation of the industry arising from 'services a la personne' are dealt with in a number of articles: see Labour Code, Partie Législative Nouvelle, Septieme Partie, Livre II, Titre III 'Services à la Personne' (arts 7231, 7232, L7233 and L7234 (ANSP), art R7232-19. See also arts L1271-1 to L1271-17 ('Chèque emploi-service universel').

51 Art L2261-15 provides that collective agreements can be extended. Arts L2261-15 to L226131 set out the conditions and procedures by which collective agreements can be so extended. See generally, M Freedland, 'Employment Law', in J Bell, S Boyron and S Whittaker, Principles of French Law (2nd edn, OUP 2007) 494. See also ILO Conditions of Work Report (n 49) 27. However note Freedland's comment that despite the fact that the conceptual approach to collective agreements remains intact, there is a great multiplicity of techniques of argument about the precise effect and duration of collective agreements (at 495).

52 Convention collective nationale des salariés du particulier employeur du 24 novembre 1999. In respect of other collective agreements for domestic workers, see Convention collective nationale des salariés du particulier employeur du 24 novembre 1999. Etendue par arrêté du 2 mars 2000 (JO du 11 mars 2000); Convention collective nationale des assistants maternels du particulier employeur du 1er juillet 2004. Etendue par arrêté du 17 décembre 2004 JORF 28 décembre 2004. Convention collective nationale de travail concernant les jardiniers et jardiniers-gardiens de propriétés privées du 30 janvier 1986. Etendue par arrêté du 27 mai 1986 JORF 8 juin 1986; Convention collective nationale de la branche de l'aide, de l'accompagnement, des soins et des 
was signed in 1999, was 'extended' by an administrative decision ${ }^{53}$ and thus applies to all domestic workers employed directly by a private individual who 'perform some or all of the household's domestic or familial tasks'. ${ }^{54}$ The terms of the collective agreement are very detailed and cover all aspects of the employment relationship including remuneration, dismissal and notice and trial periods. They also address many aspects of the 'specificity' of domestic work, including salary deductions for accommodation, ${ }^{55}$ night work (as well as working time generally and holiday entitlements) ${ }^{56}$ and required standards of accommodation. ${ }^{57}$ The provision of a written contract is required ${ }^{58}$ and a model contract is attached to the collective agreement, which provides guidance in respect of the terms of employment. 59

These provisions mirror many of those in the Domestic Workers Convention. French law recognizes domestic work as real work, constituting 'one of the most detailed attempts to gear the employment contract specifically to the domestic work relationship and enforce it in such a way as to prevent abuse'. ${ }^{60}$ However, some of the elements of the regime contained in the collective agreement, such as the right to professional training and development ${ }^{61}$ for example, are difficult to implement. ${ }^{62}$ Monitoring compliance is also problematic as French law requires a court order for the labour inspection of a private home. ${ }^{63}$ In spite of these practical difficulties of implementation, the French employment framework provides a model of regulation for other jurisdictions and conforms to the normative approach followed in the ILO Domestic Workers Convention as endorsed in General Comment of the UN Committee on Migrant Workers and the General Recommendation of the CEDAW Committee.

Recent developments in the French approach have been driven by a focus on job creation in the sector, ${ }^{64}$ which has led to a number of innovations which aim to recognize domestic workers and formalize the work sector. ${ }^{65}$ The most prominent tool used to facilitate employment in the domestic work sector is the

services à domicile du 21 mai 2010/ Arrêté du 23 décembre 2011 portant extension de la convention collective nationale de la branche de l'aide, de l'accompagnement, des soins et des services à domicile et d'avenants à ladite convention collective ( $\left.n^{\circ} 2941\right)$.

53 Arrêté du 2 mars 2000 (JO du 11 mars 2000).

55 Art 5.

57 Art 21.

${ }^{54}$ Art 1(a).

59 Model permanent contract, Annex 1 to the Collective Agreement of 1999, para 7.

60 ILO Report on Decent Work for Domestic Workers (Report IV(1)) (n 23) para 171.

61 Contained in art 25, together with the agreement contained at Annex V.

62 See F-X Devetter, F Jany-Catrice and T Ribault, Services à la personne (La Découverte 2009 ) in particular the chapter entitled 'Des métiers sans profession', 99.

63 See ILO Conditions of Work Report (n 49) 27.

64 See 'Plan de dévelopement des services à la personne' (16 February 2005) < http://travailemploi.gouv.fr/IMG/pdf/20050216_dp_presentation-plan.pdf>; 'Plan 2 de développement des services à la personne: Créer, Professionaliser, Simplifier’ (ANSP, March 2009) <http://www. servicesalapersonne.gouv.fr/Public/P/ANSP/Actus/2009/mars/20090324_Plan2.pdf>.

${ }^{65}$ For a look at some of the innovations, see J-Y Kerbourc'h, 'L'étonnant dynamisme de l'emploi à domicile' (2005) 2 Travail et Protection sociale, Alerte 29; M Borgetto, 'Les services à 
'service cheque'. In 2005, two pre-existing schemes were amalgamated and replaced by the cheque emploi service universel (CESU). ${ }^{66}$ The CESU déclaratif permits the consumer of domestic services to pay, declare and make social security contributions for the domestic worker in a simplified manner and householders can also claim an income tax reduction or credit on the cheques. ${ }^{67}$ The initiative thus facilitates the formalization of domestic work and domestic workers' full participation in the formal economy. ${ }^{68}$ While the scheme is not framed in terms of protecting domestic workers, this is a key step in the reconstructive process of moving from a status relationship to a work relationship - as emphasized by the ILO in promoting the 'decent work' paradigm for domestic workers. ${ }^{69}$

Specific barriers to formalizing the work relationship in the domestic setting include employers' reluctance to take on the administrative and financial duties attaching to their role in the employment relationship. In recognizing and seeking to address these issues, the CESU constitutes an acknowledgement that the procedures governing formal employment are restrictive and expensive for individual employers and may result in a failure to employ or employment on an informal basis. ${ }^{70}$ French NGOs have, however, pointed to continuing high levels of undeclared and informal work in private households, particularly among migrant domestic workers (and linked to the irregular immigration status of many of the migrants involved). ${ }^{71} \mathrm{~A}$ recent study of the impact of the industrialization of paid domestic work in France concluded that despite the innovations in French policy and regulation, 'Improvements in working conditions are not always evident ... and recourse to an immigrant labour force thus seems to be a solution. ${ }^{72}$ Nonetheless, the CESU, together with the collective convention, has contributed to making the domestic work sector more visible and mainstream in French discourse.

la personne' (2006) Revue de droit sanitaire et social 3; G Laforge, 'La structuration de l'offre de services à la personne après la loi du 26 juillet 2005' (2006) Revue de droit sanitaire et social 5.

66 See PY Verkindt, 'Le cheque emploi service universel' Revue de droit sanitaire et social (2006).

67 ANSP and Finances Publique, 'Déclaration des revenus 2010'. For a full analysis of the mechanism and implications of the CESU, see Verkindt, 'Le cheque-emploi service universel' (n 66). See also J Windebank, 'The Chèque Emploi-Service, the Titre Emploi-Service and the Chèque Emploi-Service Universel in France: The Commodification of Domestic Work as a Route to Gender Equality?' (2006) 14(2) Contemporary France 189; and Tomei (n 11).

68 Windebank (n 67).

70 Windebank (n 67) 194.

71 EU Fundamental Rights Agency (n 12) 19. Although as the report points out, the levels are difficult to quantify due to lack of data.

72 See also FX Devetter and S Rousseau, 'The Impact of Industrialization on Paid Domestic Work: The Case of France' (2009) 15 European Journal of Industrial Relations 297, 311. 


\section{Exemption and exclusion in UK law}

The 'specific regulation' model adopted in France mirrors the approach of some other European countries such as Sweden, ${ }^{73}$ the Netherlands ${ }^{74}$ and Spain $^{75}$, each of which have specific laws governing the employment of domestic workers. Specific regulation contrasts with the model adopted in the UK and Ireland, where domestic workers are covered by the provisions of general employment law and there are no specific legal provisions or instruments governing the regulation of domestic work as distinct from other types of work. Unlike in France, the UK and Irish governments have shown no appetite for expanding the domestic work sector as a means of job creation.

In the UK, domestic workers are covered under the provisions of general employment law. ${ }^{76}$ However, there are a number of key exemptions from the scope of labour protections in respect of domestic workers, reflecting a historical tendency to exclude domestic workers from the scope of protective employment legislation. ${ }^{77}$ Some modern employment legislation follows this exclusionary model. This includes exemptions from health and safety law and certain aspects of the regulation of working time. ${ }^{78}$ For those who are entitled to the minimum wage, deductions may be made from that wage if domestic workers receive accommodation, ${ }^{79}$ reflecting the strong worldwide trend in favour of remunerating domestic workers in kind..$^{80}$

Most notably, the requirement to pay the national minimum wage is not applicable to domestic workers in situations where they live with their employer and are treated as a member of the family, in accordance with Regulation 2(2) of the National Minimum Wage Regulations. The protection gaps arising from 'integration into the family' are demonstrated in the 2012 Employment Appeals Tribunal (EAT) decision in Julio v Jose. ${ }^{81}$ In these three joined appeals from decisions of Employment Tribunals, the EAT found that

73 See C Calleman, 'Domestic Services in a "Land of Equality": The Case of Sweden' (2011) 23 Canadian Journal of Women and the Law 121.

${ }^{74}$ See S van Walsum, 'Regulating Migrant Domestic Work in the Netherlands: Opportunities and Pitfalls' (2011) 23 Canadian Journal of Women and the Law 141.

75 See M Léon, 'Migration and Care Work in Spain: The Domestic Sector Revisited' (2010) 9(3) Social Policy and Society 409. See also 'Spain Approves New Regulations for Domestic Employees' (ILO, Developments in Law and Practice 2012).

76 See generally E Albin and V Mantouvalou, 'The ILO Convention on Domestic Workers: From the Shadows to the Light' (2012) 41 Industrial Law Journal 67.

77 See S Hardy, Labour Law and Industrial Relations in Great Britain (3rd edn, Kluwer Law International 2007); also Albin and Mantouvalou ibid.

78 See section 51 of the Health and Safety at Work Act 1974 and Regulation 19, Working Time Regulations 1998 (No 1833 of 1998) (which provides that Regulations 4(1) and (2), 6(1), (2) and (7), 7(1), (2) and (6) and (8) do not apply in relation to a worker employed as a domestic servant in a private household), respectively.

${ }^{79}$ Regulations 36 and 37 of the Minimum Wage Regulations 1999.

80 ILO Report IV(1) (n 23) 7.

81 Appeal No UKEAT/0553/10/DM, Judgment of 8 December 2011 (EAT judgment). See also M Lalani, 'Ending the Abuse: Policies that Work to Protect Migrant Workers' (Kalayaan May 2011) 22 . 
none of the migrant domestic workers involved were entitled to the minimum wage. ${ }^{82}$ The EAT found that Regulation 2(2) should be interpreted narrowly and the worker's place within the family considered holistically, with particular regard to the provision of accommodation and meals and the sharing of tasks (not including the work which the worker is employed to do) and leisure activities. ${ }^{83}$ Other matters, such as the general dignity with which the domestic worker is treated, the degree of privacy and autonomy they are afforded and the extent to which, if at all, they are exploited may also be considered in determining whether the worker is treated as part of the family. ${ }^{84}$ Applying this test, the Tribunal found that Regulation 2(2) applied to each of the three claimants involved, none of whom was entitled to the minimum wage for the hours in which they were engaged in work. ${ }^{85}$ In the case of one of the claimants, this conclusion that she was treated as part of the respondent's family was reached despite the finding that the respondent exploited the claimant's position to pay her less than she was entitled. ${ }^{86}$

\section{Invisibility and innovation: The Irish approach}

The Irish position diverges from both the French and the British approaches and constitutes a middle ground between the two. The main body of Irish employment legislation applies equally to workers employed in the private home, ${ }^{87}$ and, unlike in the UK, domestic workers are not excluded from any aspects of employment legislation. ${ }^{88}$ In fact, domestic work is striking in its absence from specific mention in the legislative provisions. Thus while domestic workers are treated as workers like any others, there is no attempt in the Irish legislative framework to recognize the problems inherent in applying both the content and spirit of employment protections within the private home or the specificity of the issues arising in the context of the employment relationship.

Although domestic workers are 'invisible' in Irish employment legislation, more recent policy developments (prompted by pressure from trade unions and migrant rights organizations) ${ }^{89}$ demonstrate a greater willingness to engage with the commodification of domestic labour than has been shown to date in the UK. The Code of Practice for Protecting Persons Employed in Other

${ }^{82}$ EAT judgment, para 58.

${ }^{84}$ ibid, para 46.

85 ibid, para 58.

83 ibid, para 46.

${ }^{86}$ ibid, para 58.

87 Minister for Jobs, Enterprise and Innovation Richard Bruton has confirmed that: 'domestic workers are protected by virtue of the fact that the full suite of employment rights legislation, including that of redress for violations of their employment rights, apply to domestic workers in the same way as they apply to other categories of employees in Ireland'. Written Answers, Dáil Éireann Debate Vol. 759 No 1 (13 March 2012) in response to a question from Gerald Nash TD.

${ }^{88}$ Although the National Minimum Wage Act 2000 makes provision for deductions from the workers' wages for board and lodging: Section 20 of the Minimum Wage Act 2000.

89 The Code of Practice was developed on foot of a social partnership agreement (see footnote infra) and the pilot inspection scheme was developed as a result of pressure from Migrant Rights Centre of Ireland (see below). 
People's Homes was drafted by the Labour Relations Commission in collaboration with union and employer representatives in 2007.90 ${ }^{9}$ The Code of Practice takes a two-pronged approach of reiterating the protections available to domestic workers in general employment law and identifying additional issues of particular concern. The employer must take reasonable steps to ensure that the employee is aware of his or her statutory entitlements as an employee. ${ }^{91}$ Some of the common problems faced by domestic workers are also addressed, for example, the employer shall not withhold any personal documentation belonging to the employee ${ }^{92}$ and, if the employee lives in the home, the employer must provide a private secure room and a bed as well as privacy of communication..$^{93}$ The emphasis on the protection of the dignity and autonomy of the employee is one of the most interesting features of the Code of Practice and it is quite far-reaching in this respect. ${ }^{94}$ The ILO singled out these provisions of the Code as an example of good practice. ${ }^{95}$ However, while the Code of Practice contains a number of innovative provisions which are protective of domestic workers and reflect ILO standards, unlike the French Collective Agreement considered above, the Code is non-binding and does not create any legally enforceable obligations, thus constituting a guide to best practice rather than an enforceable part of the regulatory framework. ${ }^{96}$

The de facto exclusion of domestic workers from the enforcement of labour regulations is a problem globally. ${ }^{97}$ The lack of monitoring of private homes as workplaces was identified by the Migrant Rights Centre of Ireland (MRCI) as one of the reasons for the continuing vulnerable position of domestic workers (particularly migrant domestic workers) despite the application in principle of labour protections to this group. ${ }^{98}$ In response to these criticisms, a pilot

90 It was agreed in section 23.2 of Part 2 of 'Towards 2016-Ten Year Framework Social Partnership Agreement 2006-2015' that the Labour Relations Commission should be asked to develop a code of practice to set out the current employment rights and protections for persons employed in other people's homes pursuant to its functions under section 42 of the Industrial Relations Act 1990. The Industrial Relations Act 1990 (Code of Practice for Protecting Persons Employed in Other Person's Homes) (Declaration) Order 1990 declared that the code of practice set out in the Schedule shall be a code of practice for the purposes of the Industrial Relations Act 1990.

91 Section 5.11.

92 For example, passport, visa, identity cards, bank account documentation. Section 5.8 .

93 Section 5.2.2. 94 Section 5.10. See also section 5.2.1.

95 ILO (n 36) 48.

96 Although note that the Code does have some evidential value: section 42(4) of the Industrial Relations Act 1990 provides that 'In any proceedings before a court, the Labour Court, the Commission, the Employment Appeals Tribunal, the Director of Equality Investigations or an equality officer, a code of practice shall be admissible in evidence and any provision of the code which appears to the court, body or officer concerned to be relevant to any question arising in the proceedings shall be taken into account in determining that question.' Section 43 provides that the Labour Court can give its opinion on the interpretation on a code of practice, investigate a complaint that there has been a breach of the code of practice and make a recommendation setting out its view on the matter.

97 ILO Report (IV)(1) (n 23) 72.

98 See 'MRCI Welcomes NERA Campaign to Protect Rights of Domestic Workers - 2010' (Press Release, 16 November 2010). See also MRCI, 'Private Homes: A Public Concern-The Experiences of Twenty Migrant Women Employed in the Private Home in Ireland' 
scheme of labour inspections of private homes was carried out by the National Employment Rights Agency (NERA) in 2011. NERA's remit in conducting these inspections is limited to that contained in the enabling legislation and the primary mode of operation provided for in that legislation is the inspection of written employment records ${ }^{99}$ as well as interviewing and obtaining information from relevant people. The inspectors' powers do not extend to the inspection of health and safety standards or living conditions of live-in domestic workers, for example, ${ }^{100}$ illustrating the limitations involved in not having any legally binding provisions governing the specific situation of domestic workers.

Despite these limitations, in international terms this scheme is an innovative one and few jurisdictions have engaged in developing such inspection programmes. ${ }^{101}$ The experiences of the scheme thus provide important lessons for regulatory regimes around Europe and beyond. NERA identified numerous challenges in the design and implementation of the inspection programme, the most significant of which was 'finding' domestic workers. Aside from cases in which complaints are received, domestic employment situations are identified primarily through an analysis of work permits and revenue records. ${ }^{102}$ This highlights the importance of issues around the formalization of domestic work, discussed in the French context above, in terms of the protection in practice of the rights of domestic workers. In addition, the way in which domestic workers are 'found' by means of state records means that the employers/employees which can be identified are probably those with the most formalized employment relationships and more likely to be compliant with employment law generally. ${ }^{103}$ Consistent with this observation, while the level of noncompliance with employment law was high, the NERA inspector noted that non-compliance related to mainly small matters and he did not find any evidence of serious abuse or exploitation. ${ }^{104}$ Although the inspections related

(Recommendation at para 3.4: 'develop a special section in the Labour Inspectorate to investigate this area of work'). See also the statistics contained in MRCI Domestic Workers Action Group Survey, 2010 and Press Release, 1 May 2012. The domestic work sector holds the second largest percentage of complaints made to MRCI.

99 NERA's website lists the standard records to which an inspector will require access to during the course of an inspection. List available at <http:/www.employmentrights.ie/en/ informationforemployers/recordstobemadeavailableforinspections/ $>$.

100 Some householders did show the inspector the accommodation provided to the domestic worker, which in his view was satisfactory, however his official remit did not include inspecting the accommodation provided.

101 S Mullally and C Kenny, 'The ILO Convention and Recommendation on Decent Work for Domestic Workers' UCC Centre for Criminal Justice and Human Rights Working Paper (April 2012); M Galotti, 'The Gender Dimension of Domestic Work in Western Europe', No 96 International Migration Papers (International Labour Office, Geneva, 2009) 61. See also ILO Conditions of Work Report (n 49).

102 See NERA Briefing of January 2011 and also updated undated briefing (copies on file with the author).

103 As pointed out by NERA in its updated briefing.

104 Semi-structured interview with NERA officials, 19 April 2012, carried out by the author (semi-structured interview). Updated briefing. The 'inspections revealed the need for clarity regarding the work an employee is required to perform and when they are required to perform it'. 
to a small sample of 19 households, this would appear to contradict the level of abuse documented by the MRCI. ${ }^{105}$ The biggest challenge to the enforcement of employment protections identified by inspectors in the course of the inspection process was the issue of calculating working time for live-in domestic workers, ${ }^{106}$ impacting the inspector's ability to determine if the minimum wage is being paid. ${ }^{107}$ This underlines some of the difficulties which can arise when domestic workers become 'integrated into the family' making it difficult to determine when they are working and tasks which they are expected to do.

One of the primary reasons why labour inspections are generally considered to be problematic in the context of the domestic work sector is the legal protection of the inviolability of the private home which is provided for in most jurisdictions, meaning that inspectors cannot enter such premises without permission. ${ }^{108}$ In Ireland, the inviolability of the private home is the only specific legal limitation on the inspection of private homes compared to other workplaces. ${ }^{109}$ However, in NERA's view, this 'in no way inhibited' the implementation of the pilot scheme, as 75 per cent of the employers consented to the inspector inspecting the records in the home concerned and the remainder arranged that the employment records be examined at an alternative location. This finding provides an important counter-argument to that of governments who maintain that inspection of private homes is legally and practically unworkable. ${ }^{110}$

\section{Divergence and Commonality in the Regulation of Domestic Work: Prospects for Reform}

The discussion above of the law in France, the UK and Ireland illustrates the diversity of approaches to the regulation of domestic work, which was part of

105 MRCI Press Release, 30 April 2012: 'In recent years MRCI has uncovered over forty cases of forced labour and domestic servitude. We have also seen a marked increase in the exploitation of domestic workers employed by embassies and diplomatic staff in Ireland.'

106 Semi-structured interview.

107 The method of calculating the employee's average hourly rate of pay is set out in section 20 of the National Minimum Wage Act 2000.

108 EUFRA report (n 12) 38: 'Labour inspectors usually play a secondary role, as their power to carry out inspections in private homes is limited. They can generally intervene only after employees report infractions. Court orders or similar permissions are usually required to conduct checks inside private households.' See also Galotti (n 101) 23. See also Smith, 'Aging and Caring in the Home: Regulating Paid Domesticity in the Twenty-First Century' (n 24), in relation to health and safety inspections. See also the EU position that the private home is not a normal workplace: Committee on Domestic Workers 2011, para 631.

109 See Procedure 3.5, NERA Case Management Manual (1 May 2011). This is noted by NERA in its January 2011 briefing. The enabling legislation generally states: 'An inspector shall not, except with the consent of the occupier, enter a private dwelling (other than a part of the dwelling used as a place of work) unless he or she has obtained a warrant from the District Court under subsection $(X)$ authorising the entry.' See section 33 of the National Minimum Wage Act 2000, for example.

110 See ILO Report (IV)(1) (n 23). 
the reason that the negotiation of the Domestic Workers Convention was a difficult process. ${ }^{111}$ The UK government's refusal to support the Domestic Workers Convention fits with its exclusionary model of exemptions and exclusions from employment law for domestic workers. In France and Ireland, attempts have been made to address specific aspects of the experience of domestic workers, through specific legislative and 'conventional' protection and targeted enforcement campaigns respectively. These provide examples of practices which a legal order should be striving to follow in order to adequately protect domestic workers' employment-related rights, and they were among the 'creative regulatory experimentations' drawn on by the ILO in developing the standards set out in the Convention. ${ }^{112}$ In addition, regulatory efforts in France to formalize the domestic work sector go further than the requirements of the Domestic Workers Convention and play an important role in constructing domestic work as 'real' work.

Despite the existence of these elements of good practice in the regulatory frameworks in France and Ireland, however, it cannot be said that a holistic or fully effective approach to the protection of domestic workers has been taken in either jurisdiction. None of the regimes examined meet the full range of standards enshrined in the Domestic Workers Convention, particularly in relation to the obligations to ensure effective access to justice (Article 16) and provide effective and accessible compliance mechanisms (Article 17). UK employment legislation contains serious gaps in coverage for domestic workers. In France, effective enforcement remains a key issue, while Irish law lacks binding provisions which take into account the characteristics of domestic work. It is also noticeable that in spite of their attempts to deal with the issues faced by domestic workers, neither the French Collective Agreement nor the Irish Code of Practice contains specific provisions on migrant domestic workers and these employment protections are not linked in any way to migration law.

Overall, access to law for domestic workers suffering the everyday indignity of sub-standard terms and conditions of work is limited in each of the jurisdictions, in different ways. In this way, '(l)aw entrenches the prevailing social values that... downplay reproductive work, even when commodified'. 113 The ILO has observed that decent work for domestic workers will remain an 'unrealised promise' unless there is concerted action to improve the legislative framework. ${ }^{114}$ A model regulatory framework in this sphere would thus encompass legislative measures to ensure the extension of decent work standards to domestic workers (using the Domestic Workers Convention

\footnotetext{
111 See generally, Albin and Mantouvalou (n 76) 67; see also Mullally and Kenny (n 101) 16 ff.

112 ILO Report (IV)(1) (n 23) 3.

113 G Mundlak and H Shamir, 'Between Intimacy and Alienage: The Legal Construction of Domestic and Carework in the Welfare State' in H Lutz (ed) Migration and Domestic Work: A European Perspective on a Global Theme (Ashgate 2008) 161, 166.

114 ILO Report (IV)(1) (n 23) 3.
} 
as guidance), together with the development of innovative, legislative and administrative mechanisms aimed at increasing formalization and improving effective enforcement. This would combat both the legal and practical obstacles to rights protection faced by MDWs and constitute a significant step towards 'a transition from the paternalistic conception of the "good employer", acting out of a sense of noblesse oblige, to one that is founded on respect for domestic workers' labour rights'. ${ }^{115}$

III. RESTRICTING SECURE LEGAL MIGRATION PATHS FOR DOMESTIC WORKERS: CAUSES, CONSEQUENCES AND PROSPECTS

\section{A. The Connection between Immigration Status and Rights for Migrant Domestic Workers: Assessing International Standards}

Despite the demand for domestic workers, few European countries issue work permits for the purpose of domestic work. ${ }^{116}$ The Europe-wide trend in favour of imposing restrictions on admission of migrants for female-dominated occupations ${ }^{117}$ is a particular problem in the case of domestic workers, with few legal avenues being opened to meet the growing demand for such workers. ${ }^{118}$ As the next section will illustrate in the context of France, Ireland and the UK, governments are refusing to acknowledge the need for migrant domestic workers, which has resulted in a lack of secure migration routes for this group of women.

The vulnerability of migrant domestic workers 'throughout the migration cycle' is considered in detail in the UN Committee on Migrant Workers' 2011 General Comment on migrant domestic workers. As well as highlighting the impact of labour law, the general comment acknowledges that immigration law can be a source of 'specific vulnerabilities' for migrant domestic workers, most notably where immigration laws tie their status to the continued sponsorship of specific employers. ${ }^{119}$ According to the Committee, sponsorship systems reduce the liberty of movement of workers and increase the risk of exploitation, including forced labour and servitude. ${ }^{120}$ In short, workers are unlikely to pursue legal proceedings against the person on whom their immigration status depends. Illustrating this, the ' $k$ afala' system of sponsoring migrant domestic workers practised in many of the Gulf States has been identified by the UN Human Rights Committee (amongst others) as a particular source of exploitation. ${ }^{121}$

115 ibid 13.

116 Galotti (n 101) 28.

117 Council of Europe Parliamentary Assembly Committee on Migration, Refugees and Population, Report on 'Protecting Migrant Women in the Labour Market' (Doc 12549, 24 March 2011).

118 EU Fundamental Rights Agency (n 12) Chap 1, 'The Gap between Demand and Supply'.

119 CMW General Comment (n 13) para 21.

121 Concluding Observations of the UN Human Rights Committee in Respect of Kuwait, 17 October 2011, para 18. See also Human Rights Watch, 'Walls at Every Turn: Abuse of Migrant Domestic Workers through Kuwait’s Sponsorship System’ (HRW 2010). 
In order to address the 'specific vulnerabilities' identified, the Committee recommends that states ensure that migrant domestic workers have access to regular channels for migration based on actual demand and avoid making immigration status conditional on employment by a specific employer. ${ }^{122} \mathrm{In}$ addition, it states that family reunification should be facilitated for those with a regular immigration status. ${ }^{123}$ These workers should also enjoy equal treatment with nationals in relation to social and health services. ${ }^{124}$ Reflecting the real difficulties in accessing justice and remedies for those with a temporary and/or tied immigration status, states are encouraged to facilitate expedited proceedings to address complaints by such migrant domestic workers. ${ }^{125}$ Finally, special mechanisms which would facilitate access to redress are endorsed-for example, the designation of a domestic workers' Ombudsperson. ${ }^{126}$

The work of the CEDAW Committee, as well as the Parliamentary Assembly of the Council of Europe, while not as detailed, supports the approach of the Committee on Migrant Workers. The CEDAW Committee in its 2008 General Recommendation on women migrant workers clarified that it views the exclusion of certain female-dominated occupations from visa schemes as indirect discrimination against women. ${ }^{127}$ In 2010, the Parliamentary Assembly of the Council of Europe passed a resolution urging member states to 'develop independent visa schemes for migrant domestic workers and care workers which would allow legal entry, provide a standardized working contract, allow for a change of employer ... and ensure that visas are not tied to particular employers'. ${ }^{128}$ Together, the standards recommended by these international and regional bodies provide the contours of an appropriate immigration regime for migrant domestic workers.

\section{B. National Approaches to the Regulation of Immigration for Domestic Workers}

\section{Absence of long-term legal channels of immigration in France and Ireland}

Work permits for migrant domestic workers are, in principle, part of the general work permit system in Ireland and in France; however, through specific restrictions in place, migrant domestic workers are excluded from obtaining an ordinary work permit. In Ireland, migrant domestic workers would be required to obtain a work permit under the Employment Permits Act 2003 (as amended) and the surrounding administrative framework. Under the relevant

122 CMW General Comment (n 13) paras 51-53.

123 CMW General Comment (n 13) paras 54-55.

${ }^{124}$ CMW General Comment (n 13) para 42.

125 CMW General Comment (n 13) para 50.

127 CEDAW General Recommendation (n 17) para 11.

128 Protecting Migrant Women in the Labour Market. Report of the Committee on Migration, Refugees and Population. Ms Pernille Frahm. Parliamentary Assembly of the Council of Europe http://assembly.coe.int/Documents/WorkingDocs/Doc11/EDOC12549.pdf). 
administrative scheme, however, a limited number of job categories are deemed ineligible for such permits. Prior to 2009, the job category of 'domestic work' was ineligible for a work permit but many domestic workers entered the country on the basis of a work permit issued for the purposes of working as a childminder, mother's aid, care worker, or nanny. ${ }^{129}$ MRCI's research showed that this often formed the basis for a false job description and ill-defined employment relationship which could in turn lead to exploitation. ${ }^{130}$ The Irish government's response to the problems associated with this migration route was to close it, and since April 2009, all domestic workers, including carers in the home and childminders and nannies, have been included on the list of ineligible job categories and are thus excluded from obtaining a work permit. $^{131}$

This inaccessibility of legal channels of migration to migrant domestic workers is reflected in French law, despite the approach followed there, as described above, of treating domestic work as a distinct work sector with its own forms of regulation. Work permits for domestic workers in France fall under the general work permit regime, which works on the basis of occupational lists which define the categories of occupation for which work permits are available. A number of categories of domestic work feature on the occupational list for migrants from Romania and Bulgaria, ${ }^{132}$ including household workers, ${ }^{133}$ home carers ${ }^{134}$, child carers, ${ }^{135}$ and nurse's aides. ${ }^{136}$ However, domestic work is not included on the occupational list for non-EEA nationals. ${ }^{137}$ In addition, bilateral migration agreements between France and African countries generally do not provide for migration for domestic work. ${ }^{138}$ Notwithstanding the inaccessibility of mainstream migration routes in France, temporary work permits are available to allow foreign domestic workers to accompany their overseas employers to France for short periods of three months at a time. Foreign domestic workers may obtain temporary work permits under Article L1262-1 of the Labour Code, which allows for employers to apply for the 'secondment' or temporary assignment of their workers in France. ${ }^{139}$ A work permit for one year may be issued, but it is not

129 MRCI, 'Private Homes, A Public Concern: The Experience of Twenty Migrant Women Employed in the Private Home in Ireland', 21.

130 ibid 21.

131 Ibid Appendix A.

132 Arrêté du 18 janvier 2008 relatif à la délivrance, sans opposition de la situation de l'emploi, des authorisations de travail aux ressortissants de Etats de l'Union européene soumis a des dispostions transitoires.

133 'Employé de ménage à domicile'.

134 'Intervenant à domicile'.

135 'Intervenant aupres des enfants'. 136 'Aide-soignant'.

137 Arrêté du 18 janvier 2008 relatif à la délivrance, sans opposition de la situation de l'emploi, des authorisations de travail aux étrangers non ressortissants d'un Etat membre de l'Union européenne, d'un autre Etat partie à l'Espace économique européen ou de la Confédération Suisse.

138 EUFRA (n 12).

${ }^{139}$ Art L1262-1-3 of the Labour Code and Circular NOR IMIM0900078C of 3 August 2009. The Circular introduces a simplified procedure for applying for the work permit, involving the filing of a form with the relevant authorities. 
valid for stays of over three months in a six-month period. While in France, these workers are covered by French employment law including minimum wage legislation, ${ }^{140}$ and employers are required to pay social security contributions for the workers. ${ }^{141}$ However, these arrangements are very temporary in nature and do not give this category of migrant domestic workers a status independent of their employer. They are not permitted to change employer once in France, meaning that they are 'tied' to their employer for their work permit. Despite the fact that these workers are, in principle, protected by French employment law, ${ }^{142}$ their legal immigration status thus places them in a precarious position of dependency in respect of their employer. This is quite similar to the visa regime for domestic workers introduced in the UK in 2012, as discussed below. ${ }^{143}$

\section{UK immigration 'reform' and the overseas domestic worker visa}

On the same day that it abstained from the vote on the Domestic Workers Convention, the UK Government announced a consultation which would result in sweeping changes to the Overseas Domestic Worker (ODW) visa regime. ${ }^{144}$ These changes rolled back immigration law reforms achieved through years of political mobilization by migrant domestic workers. From 1998 until 2012, following a long campaign by the Waling-Waling and Kalayaan migrant domestic workers' associations, ${ }^{145}$ the UK Immigration Rules ${ }^{146}$ provided for a specific status for migrant domestic workers working in private households by way of the ODW visa. The ODW visa was granted for a period of up to 12 months, ${ }^{147}$ which could be extended for 12 months at a time. ${ }^{148}$ Crucially, under the terms of the visa, domestic workers were permitted to change employer as long as they remained in the domestic work sector. Family reunification was provided for as dependents could apply to go with the migrant domestic worker to the UK or to join them there. ${ }^{149}$ Migrant domestic workers also had a pathway to long-term residence and citizenship_-providing a possible route out of temporary immigration status for migrant domestic workers. ${ }^{150}$ Despite difficulties with some aspects of the status afforded by

\footnotetext{
140 Art L1262-1-4 of the Labour Code.

141 Circular NOR IMIM0900078C of 3 August 2009, referring to the provisions of Article R312-4 of the Social Security Code.

${ }^{142}$ Circular NOR IMIM0900078C of 3 August $2009 . \quad{ }^{143}$ Lalani (n 81).

144 UK Border Agency, 'Employment-Related Settlement, Tier-5 and Overseas Domestic Workers: A Consultation' (June 2011) (Consultation Paper).

145 See generally B Anderson, 'Mobilizing Migrants, Making Citizens: Migrant Domestic Workers as Political Agents' (2010) 33(1) Ethnic and Racial Studies 60.

146 The Immigration Rules 1994 HC 395 (as amended) (Immigration Rules).

147 Formerly para 159B of the Immigration Rules.

148 Formerly para $159 \mathrm{E}$ of the Immigration Rules.

149 This was not set out in the Immigration Rules but was accepted practice.

150 As they could qualify for 'indefinite leave to remain' if they met the criteria laid down in Immigration Rule 159G.
} 
the visa, including narrow eligibility conditions ${ }^{151}$ and practical difficulties associated with trying to find alternative similar employment in the event of leaving the employer, ${ }^{152}$ the regulatory framework of the ODW visa provided a relatively secure legal status which implied respect for family unity and included the potential for long-term settlement. This is broadly in line with the recommendations on appropriate immigration law regimes for migrant domestic workers made by the UN Committee on Migrant Workers.

Research conducted by the migrant domestic workers' NGO Kalayaan showed that the option to change employer provided for by the ODW visa played a vital role in enabling migrant domestic workers to escape from abusive employers, in empowering them to negotiate fairer terms and conditions and in facilitating the pursuit of legal remedies against their employers. ${ }^{153}$ In the views of a House of Commons Select Committee on Human Trafficking in the UK convened in $2009^{154}$ and the United Nations Special Rapporteur on the Human Rights of Migrants, ${ }^{155}$ the ODW visa also helped to reduce the incidence of trafficking and forced labour among migrant domestic workers. This direct linkage of the ODW visa to preventing forced labour and trafficking is especially important in the context of the European Court of Human Rights' recognition of the links between immigration status and vulnerability to exploitation in its judgment in Rantsev $v$ Cyprus and Russia. ${ }^{156}$ The evolving ECHR jurisprudence on the extent of states' positive obligations of protection in respect of the prohibition on slavery, servitude and forced labour in Article 4 ECHR is considered further in the next section.

In spite of the recommendations of the House of Commons Select Committee and the UN Special Rapporteur, in February 2012, it was announced that the Immigration Rules would be amended to provide that ODWs in private households will only be permitted to accompany and work for visitors. ${ }^{157}$ They must leave the UK with the visitor, or after a maximum of six months. ${ }^{158}$ They may not extend their stay, switch employer, sponsor dependants or gain long-term residence ('settle') in the UK. ${ }^{159}$ The terms of the revised ODW visa thus resemble closely those of the temporary 'secondment' work permit available in France.

151 Formerly para 159A of the Immigration Rules.

152 See Lalani (n 81).

153 Lalani (n 81) 18-21.

154 House of Commons, Home Affairs Select Committee, Sixth Report of Session 2008-2009, The Trade in Human Beings: Human Trafficking in the UK, HC 23-I, 14 May 2009, paras 118-119.

155 UN Human Rights Council, Report of the Special Rapporteur on the human rights of migrants, Addendum: Mission to the United Kingdom of Great Britain and Northern Ireland, 16 March 2010, A/HRC/14/30/Add.3, p. 15 and 16, and recommendation at para 76.

156 Application No 25965/04, Judgment of 7 January 2010.

157 Home Office Announcement, 'Immigration (Employment-related settlement, Overseas Domestic Workers, Tier 5 of the Points Based System and Visitors)', 29 February 2012.

${ }_{158}$ Paras 159A(iv) and 159B of the Immigration Rules.

159 Paras 159A(vi), 159G(i) and 159E of the Immigration Rules. 
Under the temporary work permits available to migrant domestic workers in both the UK and France, such workers benefit from the normal range of employment protections. However, in practice, the time limit imposed on the visa combined with the restriction on changing employer prevents the worker from enforcing these rights. In the case of the UK, Kalayaan points out that these factors effectively prevent the worker from seeking justice through the employment tribunal system; they would have no right to stay in the UK for the tribunal case and would be unable to work to support themselves or their families whilst they wait for the case to come to tribunal. ${ }^{160}$ There is no provision for granting residence permits to such individuals who are seeking redress through the employment law system in the UK or France. The entitlement to residence permits and protection from expulsion during labour procedures (as opposed to criminal prosecutions for trafficking or forced labour offences) has been identified by the EU Fundamental Rights Agency as a crucial element in ensuring effective remedies for migrant domestic workers. ${ }^{161}$ In the absence of such measures, the protection afforded by the employment frameworks discussed in the first section is largely illusory.

The changes to the UK Immigration Rules came into effect on 6 April 2012. ${ }^{162}$ The primary justification offered for the move towards a more precarious, temporary status was the perceived skill level attached to domestic work. Migrant domestic workers were considered by the Government to generally be doing low-skilled work, and allowing such unrestricted lowskilled entry for an extended period was seen as running counter to the Government's wider policy of restricting numbers of low-skilled workers. ${ }^{163}$ The perception of domestic work as an atypical, 'low-skilled'164 form of work, to be performed by someone who becomes a surrogate 'member of the family' rather than a worker with full employment (and immigration status) is evident in the discourse in the UK surrounding both the Domestic Workers Convention and the 'reform' of the ODW visa. ${ }^{165}$ In immigration law terms, these factors have resulted in domestic workers being framed as undesirable migrants. Overall, current UK law and policy reveals a retreat from a framework premised on a rights-based paradigm of domestic work.

\footnotetext{
160 Kalayaan, 'Response to "Employment-Related Settlement, Tier-5 and Overseas Domestic Workers: A Consultation"” (5 August 2011).

161 EUFRA Report (n 12) 39.

162 Home Office Announcement, 'Immigration (Employment-related settlement, Overseas Domestic Workers, Tier 5 of the Points Based System and Visitors)', 29 February 2012, 2; Lord Reay, House of Lords 28 November 1990 c1052.

163 Consultation Paper, 29. See also National Institute of Social and Economic Research (commissioned by the Migration Advisory Committee, 'Skilled Immigration and Strategically Important Skills in the UK economy' (17 January $2012<$ http://www.ukba.homeoffice.gov.uk/ sitecontent/documents/aboutus/workingwithus/mac/research-skill/niesr-skilled.pdf?view=Binary $>$ ).

164 Consultation Paper, 29.

165 In relation to the ILO Convention, see eg HL Deb Col WA242 (Baroness Wilcox) (12 October 2011); HC Deb cols 288-289 (Ed Davey MP) (29 June 2011). In relation to the ODW visa, see eg Consultation Paper, ibid; Home Office Announcement (n 162).
} 


\section{Converging Exclusionary Immigration Regimes and Exploring Alternative Models}

Part I of this article outlined the employment protections that apply (or not) to domestic workers. Part II has illustrated that each of the jurisdictions examined show a marked tendency towards limiting access to secure migration channels for domestic workers coming from outside the EU, a shift which has been particularly controversial in the UK. The general lack of explicit recognition in immigration policies of the need for migrants to carry out domestic work ${ }^{166}$ does not stop this work being carried out, and these workers 'endure the difficult conditions of life in a twilight zone'. ${ }^{167}$ Domestic workers enter Europe with a wide range of immigration statuses outside the regular work permit system, ${ }^{168}$ including admission via temporary work permits, au pair programmes, spousal or dependent residence permits and as sponsored employees of diplomats. ${ }^{169}$ Some European states, such as Italy, have established annual quotas for women migrant domestic workers, ${ }^{170}$ and regularization schemes for irregular migrant domestic workers have been implemented in Italy, Greece and Spain. ${ }^{171}$ Most of the immigration statuses conferred under these various schemes are precarious in the sense of being of a limited duration and/or dependent in some way on the legal status of another person.

These trends are evident in the temporary immigration statuses available to migrant domestic workers in the UK and France discussed above- which are time-limited and not open to renewal, and do not provide for family reunification or a path to settlement. It was seen that the conditions attached to these visas effectively restrict access to legal protections contained in the employment regime. Ultimately, as the work is not ascribed any economic value, no incentive is provided to attract migrant domestic workers and the resulting immigration statuses do not attempt to give these women a secure

\footnotetext{
166 'Rights of Migrant Domestic Workers in Europe' (UN Human Rights, Office of the High Commissioner Europe Regional Office 2010) at 10.

${ }^{167}$ H Lutz, 'When Home Becomes a Workplace: Domestic Work as an Ordinary Job in Germany?' in H Lutz (ed) Migration and Domestic Work: A European Perspective on a Global Theme (Ashgate 2008) 43, 49.

169 (Ast Galti (n 101). trafficked? - Recruitment, residence in Denmark and dreams for the future, A qualitative study of the prevalence and risk of human trafficking in the situations and experiences of a group of au pairs in Denmark' (2010); Office of the Special Representative and Co-ordinator for Combating Trafficking in Human Beings, Organization for Security and Co-operation in Europe, 'Unprotected Work, Invisible Exploitation: Trafficking for the Purpose of Domestic Servitude', (OSCE 2010). See also A Kartusch, 'Domestic Workers in Diplomats' Households: Rights Violations and Access to Justice in the Context of Diplomatic Immunity' (German Human Rights Institute 2011).

${ }^{170}$ F van Hooren, 'When Families Need Immigrants: The Exceptional Position of Migrant Domestic Workers and Care Assistants in Italian Immigration Policy' 2(2) Bulletin of Italian Politics (2010) < http://gla.ac.uk/media/media_194307_en.pdf > 21-38.

171 See generally León (n 75); F Scrinzi, 'Migrations and the Restructuring of the Welfare State in Italy: Change and Continuity in the Domestic Work Sector' in H Lutz (ed) Migration and Domestic Work: A European Perspective on a Global Theme (Ashgate 2008) 29.
} 
place in society or a real voice - a position which is anathema to the 'decent work' paradigm advocated by the ILO. The causative connection between the lack of legal immigration channels for domestic workers and the high degree of irregularity in the sector has been identified by the EU Fundamental Rights Agency, among others. ${ }^{172}$ The Irish approach, which is to block this route for legal migration altogether, potentially diverts all new migrant domestic workers into irregularity and even greater susceptibility to exploitation. ${ }^{173}$

An alternative approach, which would acknowledge the demand for migrant domestic workers as well as the vital care functions which these workers perform, would be to adopt immigration regulations in line with the normative model set out by the Committee on Migrant Workers and the Parliamentary Assembly of the Council of Europe. This model was shown to work to protect migrant domestic workers in the UK in the period between 1998 and 2012. Independent visa schemes for domestic workers, which would allow them to change employer, enjoy family unity and gain access to social protection would conform to this paradigm. In the key area of the enforcement of labour protections, a secure and independent status would also facilitate access to law and remedies, enabling such workers to negotiate fair terms and conditions and deterring employment law violations. From a human rights perspective, this constitutes an appropriate way forward for immigration regulation in this sphere. As recent 'reforms' in the UK show, however, governments are ever more reluctant to recognize the connections between immigration status, vulnerability and exploitation. In Europe, the current trend is in the opposite direction to the model immigration regime identified by international human rights bodies and there is little sign of governments changing their approach to this issue.

IV. FORCED LABOUR DIMENSIONS OF MIGRANT DOMESTIC WORK: THE POTENTIAL AND THE LIMITATIONS OF RECENT ECHR JURISPRUDENCE

\section{A. Developing Positive Obligations under Article 4: The Migrant Domestic Workers Cases}

This article has revealed a resistance on the part of states to providing safe channels of migration and effective access to law and legal remedies for migrant domestic workers. A series of cases taken by migrant domestic workers under the ECHR have highlighted the tensions between this resistance and states' human rights obligations in the context of the Article 4 ECHR prohibition on slavery, servitude and forced labour. In its seminal judgment in

172 EU Fundamental Rights Agency (n 12); CMW General Comment (n 13) para 21.

173 See CMW General Comment (n 13) para 21: 'Overly restrictive immigration laws may lead to higher numbers of migration domestic workers who are undocumented or in an irregular situation, and thus particularly vulnerable to human rights violations'. 
Siliadin v France, ${ }^{174}$ in which the applicant was a Togolese migrant domestic worker, the Court held that France had breached Article 4 in not having criminal law provisions that would allow for the penalization and effective prosecution of the act of keeping someone in a situation of forced labour. The Court noted that criminal sanctions are the only effective deterrent in these situations ${ }^{175}$ and found that the relevant French criminal provisions in place were not specific enough and were too restrictive to provide effective protection. In C.N. and $V v$ France ${ }^{176}$ and C.N. $v$ United Kingdom, ${ }^{177}$ the Court built on the positive obligations findings in Siliadin and reiterated the procedural obligation of states to effectively investigate complaints which raise 'a credible suspicion that the person has been held in domestic servitude'. ${ }^{178} \mathrm{In}$ C.N. v France, the ILO definition of forced labour as 'work performed under the menace of some penalty, and for which the person has not offered themselves voluntarily', was confirmed. ${ }^{179}$ The Court also established in that case that the notion of a 'penalty' could include psychological threats such as reporting an illegal immigrant to the police or the immigration authorities. ${ }^{180}$

As the Court noted in C.N. v UK, the Article 4 cases illustrate the 'increasingly high standard' required of states in respect of the protection of human rights and fundamental liberties, and the consequent 'firmness' of the Court in 'assessing breaches of the fundamental values of democratic societies'. ${ }^{181}$ One question which remains unresolved in the case law, however, is whether the developing 'positive obligations' of states to prevent treatment contrary to Article 4 extend to ensuring effective access to employment protections by (among other things) providing secure channels of migration for domestic workers. In Rantsev $v$ Cyprus and Russia, ${ }^{182}$ the Court established that trafficking for the purposes of sexual exploitation came within the scope of the Article 4 prohibition. Here, the Court expressly linked states' obligations to prevent trafficking to the migration regime, in finding, among other things, that the 'cabaret artiste' visa regime in place in Cyprus was known to facilitate trafficking. The State's positive obligations had been breached in retaining this immigration route. However, less direct links between migration law and trafficking or forced labour than existed in Rantsev (where the Cypriot government was shown to have known of the consequences of the cabaret artiste visa even when they introduced other anti-trafficking measures) are not as straightforward for the Strasbourg Court to recognize. In Siliadin, the applicant had entered France on a tourist visa whereupon her

174 (2006) 43 EHRR 16.

176 Application No 67724/09, Judgment of 11 October 2012.

175 ibid paras $143-145$.

177 Application No 4239/08, Judgment of 13 November 2012.

178 C.N. v UK, Application No 4239/08, Judgment of 13 November 2012, para 71.

179 C.N. and $V$ v France, Application No 67724/09, Judgment of 11 October 2012, para 71.

180 ibid para 77.

181 C.N. v UK, Application No 4239/08, Judgment of 13 November 2012, para 75.

182 Application No 25965/04, Judgment of 7 January 2010. 
papers were confiscated and she was told by her employers that her situation would be regularized - which never happened. The Court did not link the issues of immigration status, vulnerability and protection from treatment contrary to Article 4 in its judgment. In C.N. v France, the links were more explicit and the Court found that the threat of deportation could be a factor in determining whether a work situation constitutes forced labour. However, it has stopped short of linking the treatment of migrant domestic workers in a manner contrary to Article 4 to the immigration policies of states on domestic workers.

Even where it is shown that a particular immigration regime puts a migrant domestic worker at risk of treatment contrary to Article 4, it is open to States to 'remedy' the situation by closing or limiting migration routes. This approach was followed in respect of the recent changes to the ODW visa in the UK. ${ }^{183}$ During the course of the debate on the reform of the ODW visa, the UK Government made it clear that it rejected the idea that providing migrant domestic workers with a secure status was the appropriate way to address the problem of the abuse and exploitation of such workers. The blame for this exploitation was laid solely at the hands of abusive employers, rather than acknowledging the role of restrictive employment and migration laws in creating the conditions where such abuse is possible. ${ }^{184}$ According to the UK Government, the most effective approach is to limit the importation of abusive employment relationships by restricting this route of migration as much as possible. $^{185}$

\section{B. Assessing the Impact of Article 4 ECHR on Remedying the Exploitation of Migrant Domestic Workers}

States have responded to Siliadin by amending and introducing criminal legislation to deal with offences arising from conditions of slavery, servitude and forced labour. In France, Articles 225-13, 225-14 and 225-15186 of the Criminal Code were amended prior to the delivery of the judgment. ${ }^{187}$ In the UK, section 71 of the Coroner's Act 2009, providing for the offences of

183 S Mullally and C Murphy, 'Decent Work for Domestic Workers: Recognising the Migration Nexus' (paper presented at Seminar on Gender, Migration and Human Rights, EUI Florence, 18-20 June 2012) (copy on file with the author).

184 HC Deb col 101WH (10 May 2006).

185 See UK Border Agency, 'Employment-Related Settlement, Tier-5 and Overseas Domestic Workers: A Consultation' (June 2011) 30.

186 Article 34, Loi no 2003-239 du 18 mars 2003 pour la sécurité intérieure (NOR: INTX0200145L).

187 While the Court 'noted' that the legislation had been amended, it did not opine on whether the amended legislation provided practical and effective protection against the actions of which the applicant was a victim, as it was not in force at the time and therefore did not apply (para 148). The amendments were quite minimal and the relevant provisions still 'do not deal specifically with the rights guaranteed under Article 4 of the Convention, but concern, in a much more restrictive way, exploitation through labour and subjection to working and living conditions that are incompatible with human dignity' (para 142) meaning that French law is probably still in breach of art 4. 
holding a person in slavery, servitude or forced labour, was introduced. ${ }^{188}$ Ireland is almost certainly in breach of its obligations under Article 4 in failing to provide for a criminal law prohibition on forced labour or other effective protection through criminal law. ${ }^{189}$ In April 2013, the Irish government introduced the Criminal Law (Human Trafficking) (Amendment) Bill 2013, which aims to (among other things) remedy this defect. ${ }^{190}$ The case law of the European Court of Human Rights, in emphasizing states' legal obligations of effective protection and insisting on a minimum standard which states must meet in respect of deterring treatment in breach of Article 4, has thus played a crucial role in requiring states to acknowledge and address modern forms of involuntary labour.

All of this raises the broader question of the response of states to forms of exploitation not reaching the threshold of severity of 'forced labour', which are primarily addressed through the employment law framework. Measures providing for forced labour offences are, in themselves, insufficient to address the broad spectrum of employment exploitation suffered by migrant domestic workers, from underpayment of wages to inadequate rest periods and substandard live-in accommodation. ${ }^{191}$ As Mantouvalou and Albin point out, 'state intervention in very extreme situations of 'modern slavery' is not sufficient for domestic workers' protection'. ${ }^{192}$ As was noted earlier, none of the employment frameworks in France, the UK or Ireland is sufficiently developed to effectively deal with these 'lesser' forms of exploitation of domestic workers and this constitutes a source of vulnerability for domestic workers, particularly where the workers are migrants holding a precarious immigration status, or have no legal immigration status. As shown in the position taken by the UK government in the debates on the ODW visa, however, states do not accept that their 'positive obligations' of protection extend to ensuring effective access to employment protections by (among other things) providing secure channels of migration for domestic workers. This illustrates the limited impact of forced labour prohibitions for migrant domestic workers in the broader context of severely limited access to law and legal remedies.

\footnotetext{
188 V Mantouvalou, 'Modern Slavery: The UK Response' (2010) 39 Industrial Law Journal 425 .

189 See C Murphy, 'State Needs to Work on Slavery' (Irish Times, 5 January 2013).

190 Section 1 of the Criminal Law (Human Trafficking) (Amendment) Bill 2013 proposes to amend the definition of "labour exploitation" contained in the Criminal Law (Human Trafficking) Act 2008 to encompass the ILO definition of forced labour.

191 Albin and Mantouvalou (n 76) 67. See also Mantouvalou (n 188) and V Mantouvalou, 'Servitude and Forced Labour in the 21st Century: The Human Rights of Domestic Workers' (2006) 35 Industrial Law Journal 395.

192 Albin and Mantouvalou (n 76) 67. See also Mantouvalou (n 188) and Mantouvalou (n 191) 395.
} 


\section{CONCLUDING REMARKS}

Lutz and Pallenga-Mollenbeck have argued that the intersection of gender, social care and migration regimes is at the heart of the phenomenon of domestic work in Europe. ${ }^{193}$ This article has explored the slightly different question of the intersection of employment law and migration law. It has put forward the idea that the 'transformative' potential of labour law for migrant domestic workers, ${ }^{194}$ as evident in the innovative provisions of the Domestic Workers Convention for example, is often undermined by restrictions imposed by immigration law. National employment law and immigration law need to 'speak to' one another in a way which allows migrant domestic workers to effectively access legal remedies. Debates on an empowerment strategy for domestic workers which centre on standard setting in employment law must thus also take into account the impact of immigration law in the case of migrant domestic workers. ${ }^{195}$

Despite the considerable divergence in approach to the regulation of domestic work in France, the UK and Ireland, it has been shown that migrant domestic workers suffer from a lack of access to employment law protections in all three jurisdictions - albeit in different ways. Moreover, in each of the three countries considered, both the 'mismatch between the realities of the job market and employment migration policies and legislation'196 and the unwillingness of governments to acknowledge the potential of immigration law to undermine rights protection mechanisms are also clear. In common with most European countries, each of these states is reluctant to recognize human rights implications of or limits to immigration law and policies and visa regimes. At present, the precarious position of migrant domestic workers in both employment and in immigration law means that protection from the continuum of exploitation suffered by this group continues to be more 'theoretical and illusory' than 'practical and effective' 197 in Europe.

In identifying significant rights-protection gaps for migrant domestic workers at the national level and considering the causes of these gaps, this paper has also presented examples of good practice and considered potential options for ameliorating the situation. It was shown that, in the present context of limited access to law and to remedies, the impact of forced labour prohibitions is severely curtailed for migrant domestic workers. Thus, while the European Court of Human Rights has achieved much in requiring states to ensure the effective criminalization of contemporary forms of slavery, individual litigation before the Court is not a substitute for the codification of

193 H Lutz and E Palenga-Mollenbeck, 'Care, Gender and Migration: Towards a Theory of Transnational Domestic Work Migration in Europe' (2011) 19(3) Contemporary European Studies 349 .

195 ibid 6. See also D'Souza (n 11).

${ }^{194}$ Blackett (n 7) 6.

196 UN Office of the High Commissioner for Human Rights (n 5) 19.

197 Airey v Ireland [1979] 2 EHRR 305, para 24. 
protective employment and immigration rules. Engagement by governments with international standards relating to employment and immigration provides the best prospect of true reform for this category of worker. The standards set by the ILO and the UN Committee on Migrant Workers provide a good model of regulation for national employment regimes and immigration regimes, respectively. The ILO standards, in particular, draw on and build upon existing creative regulatory practices such as those developed in France and Ireland. These practices show that states are willing, at least in the sphere of employment law, to try to extend the reach of regulatory protections to domestic workers. While states may continue to be reluctant to be formally bound by the Domestic Workers Convention and the UN Convention on Migrant Workers, much could be achieved through the use of these international standards to guide regulatory development at the national level. 